\title{
MEMBANGUN DESAIN HUBUNGAN INDUSTRIAL DALAM MENCAPAI KEHARMONISAN ANTAR PEGAWAI DENGAN MANAJEMEN DI UBP KARAWANG
}

\author{
Enjang Suherman \\ enjangsuherman@ubpkarawang.ac.id \\ Universitas Buana Perjuangan Karawang
}

\begin{abstract}
Abstrak
Hubungan industrial di lembaga perguruan tinggi meliputi yayasan, rektorat (pimpinan), dosen, dan tenaga kependidikan. Perilaku organisasional atau hubungan industrial tentu saja harus harmonis. Apabila terjadi perselisihan maka yayasan, rektorat dan pegawai duduk bersama dan mencari solusi serta bisa menyampaikan pendapat, sehingga musyarawah untuk mufakat bisa diutamakan.

Penelitian ini menggunakan metode penelitian pendekatan deskriptif kualitatif. Populasi yang digunakan dalam penelitian ini adalah civitas akademik yang berbekerja di UBP Karawang. Teknik pemilihan sampel menggunakan cluster sampling. Adapun metode analisis yang digunakan berupa analisis deskriptif yakni menganalisis hasil jawaban pertanyaan responden yang diinterprestasikan dengan kaitannya masalah hubungan industrial.

Hasil penelitian ini berupa hubungan industrial yang harmonis dapat dipengaruhi oleh peran pimpinan melalui pendekatan kepada pegawai dengan komunikasi yang efektif dan bersifat empati kepada dalam hal menyikapi perselisihan.

Peran pimpinan untuk membangun hubungan industrial yang harmonis dengan cara membuat pertemuan pimpinan secara rutin. Komunikasi efektif, perencanaan dan pengawasan secara keseluruhan, negosiasi, empati kepada pegawai adalah sebagai kompetensi utama. Apabila terjadi perselisihan, pimpinan sebagai mediator dan diselesaikan secara internal.
\end{abstract}

\section{Pendahuluan}

Berbagai kepentingan antar pihak mewajibkan lembaga perguruan tinggi membuat peraturan-peraturan mengenai kepentingan tersebut. Keharmonisan hubungan tentu akan mempunyai dampak terhadap hasil kinerja, baik kinerja individual maupun kinerja lembaga.

Hubungan industrial di lembaga perguruan tinggi ini meliputi yayasan, rektorat, dosen, dan tenaga kependidikan. Yayasan mengelola kekayaan dan pelaksanaan kegiatan pendidikan tinggi dengan berbagai kebijakan meliputi tatakelola, keuangan, administrasi umum, sarana prasarana bahkan bidang akademik. Sedangkan rektorat merupakan pimpinan institusi yang 
mewakili yayasan yang bertugas menjalankan kebijakan yang telah ditentukan oleh yayasan. Rektorat mengelola penyelenggaraan perguruan tinggi berupa program pembelajaran, strategi organisasi, membina hubungan kerjasama dengan lingkungan universitas, dan stakeholder lain, menyusun rencana kerja tingkat universitas, mengelola kekayaan universitas secara optimal, dan membina tenaga edukatif.

Dosen dan tenaga kependidikan merupakan pegawai lembaga universitas yang menjalan tugas pokok dan fungsinya sebagai pegawai. Tugas pokok sebagai dosen menjalakan aktivitas tridharma perguruan tinggi meliputi pendidikan dan pengajaran, penelitian, pengabdian kepada masyakat dan kegiatan penunjang lainnya. Sedangkan tenaga kependidikan hanya menjalakan tugas pokok tentang keadministrasian.

Dalam perkembangannya, hubungan industrial tidak hanya menekankan pada aspek pengaturan yang tertuang dalam undang-undang ketenagakerjaan dan berbagai peraturan lainnya, melainkan menggali aspek lain mengenai hubungan industrial. Hubungan industrial membahas hubungan individu, kelompok, dan organisasi. Hal ini tentu saja mirip dengan perilaku organisasional dan manajemen sumber daya manusia, tetapi kajiannya tentu saja berbeda.

Perilaku organisasional atau hubungan industrial tentu saja harus harmonis. Apabila terjadi perselisihan yang tidak bisa diselesaikan dengan benar, maka akan menimbulkan ketidakpuasan pegawai. Akan tetapi, hal ini tersebut juga mungkin dapat dihindari jika yayasan, rektorat dan pegawai duduk bersama dan mencari solusi serta bisa menyampaikan pendapat yang lebih konstruktif, sehingga musyarawah untuk mufakat bisa diutamakan dibandingkan dengan melakukan tindakan lainya yang dapat merugikan.

Dampak yang timbul karena adanya ketidak harmonisan hubungan industrial antara lembaga dengan pegawai adalah tingkat kesejahteraan pegawai. Ketidakpuasan akan tingkat kesejahteraan mengakibatkan dampak lebih serius. Seperti tidak berjalannya aktivitas atmosfir akademik, penurunan kinerja, retensi pegawai, sampai keluar dari pekerjaan.

Ketidak harmonisan pegawai dengan lembaga atau pimpinan mengindikasikan bahwa pimpinan kurang memiliki kemampuan untuk berkomunikasi dua arah dengan pegawai serta mencerminkan kurang profesional pimpinan dalam melaksanakan tugasnya sebagai pimpinan. Tugas seorang pimpinan adalah mengarahkan, mengayomi dan melindungi bawahannya.

Ketidakharmonisan terjadi karena kurangnya kompetensi pimpinan dalam berperilaku kepada pegawai, dan keahlian berkomunikasi yang dapat menimbulkan kerugian bagi lembaga di masa mendatang.. 
Sudah barang tentu pimpinan sudah tidak lagi membuang banyak waktu memeriksa absensi pegawai, dan pekerjaan administrasi lainnya yang dapat didelegasikan kepada staf yang lebih spesialis, sehingga pimpinan sudah harus fokus untuk memikirkan strategi-strategi yang berorientasi kepada kelangsungan perkembangan lembaga dalam mencapai visi dan misi yang akan datang.

Penelitian ini, penulis berfokus bagaimana pengembangan Universitas Buana Perjuangan Karawang (UBP Karawang) dalam membangun hubungan industrial dalam mencapai keharmonisan antar pegawai dengan Top Manajemen (yayasan dan pimpinan) yang selama ini diperhatikan tidak ada pertikaian antar pimpinan dengan pegawai.

\section{Rumusan Masalah}

Berdasarkan uraian pada latar belakang masalah, maka ada dua rumusan masalah dalam penelitian ini.

1. Apa yang mempengaruhi keharmonisan hubungan industrial di UBP Karawang

2. Bagaimana peran Pimpinan dalam membangun keharmonisan hubungan industrial di UBP Karawang?

\section{Tinjauan Pustaka}

\section{Hubungan Industrial}

Hubungan Industrial merupakan kegiatan yang mendukung terciptanya hubungan harmonis antar pengusaha (manajemen), pegawai dan pemerintah, sehingga tercapainya ketenangan bekerja dan kelangsungan berusaha (Industrial Peace). Pada Undang-Undang No 13 Tahun 2003 tentang Ketenagakerjaan pasal 1 angka 16 menyatakan bahwa Hubungan Industrial merupakan "Suatu sistem hubungan yang terbentuk antara para pelaku dalam proses produksi barang dan/atau jasa yang terdiri dari unsur pengusaha, pekerja/buruh dan pemerintah yang didasarkan pada nilai-nilai Pancasila dan UndangUndang Dasar Negara Republik Indonesia tahun 1945.” oleh sebab itu, masalah hubungan industrial harus mendapatkan perhatian khusus dalam penanganannya, karena akan berpengaruh besar terhadap kelangsungan proses aktifitas atau kegiatan yang terjadi di perusahaan.

Menurut Idris (2018) Konsep Hubungan industrial adalah "konsep yang mengatur hubungan antara sumber daya manusia suatu organisasi industrial dengan para pemilik modal yang mendanai organisasi industrial tersebut. Hubungan industrial merupakan seperangkat aturan tertentu yang mengatur hak dan kewajiban para pihak di dalam proses 
produksi suatu produk industri."

Kesinambungan dan keseimbangan antar pengusaha dengan pekerja merupakan tujuan yang hendak dicapai sehingga terjadi keharmonisan hubungan antar pekerja dengan pengusaha. Hubungan antar pekerja dengan pengusaha merupakan hubungan yang saling membutuhkan serta saling mengisi satu sama lainnya. Pengusaha tidak dapat melakukan usahnya jika tidak didukung oleh pekerja, demikian pula sebaliknya pekerja tidak akan dapat kesejahteraan tanpa adanya kegiatan usaha pengusaha.

Aktor Utama dalam hubungan industrial adalah (Idris, 2018): (1) Manajemen atau asosiasi pengusaha; (2) Buruh dan serikat pekerja. Terarah untuk mendapatkan gaji yang laiak dan lingkungan kerja yang baik dari manajemen; (3) Otoritas pemerintah terdiri dari legislatif, eksekutif dan yudikatif. Legislatif atau wakil rakyat, Eksekutif atau pemerintah, dan Yudikatif adalah pengadilan hubungan industrial.

Ariani (2014) mengatakah bahwa Fungsi manajemen dalam hubungan industrial yaitu mencapai tingkat usaha kerja fisik dan mental karyawan. Manajemen harus menjamin karyawan melakukan pekerjaan yang harus dilakukan untuk mencapai standar yang ditentukan. Dengan supervisi yang ketat dan pembagian kerja secara detai,1 manajemen dapat mencapai sasaran dan mampu mengendalikan apa yang dikerjakan pekerja.

Usaha manajemen dalam melaksanakan tugasnya diperlukan peraturan di tempat kerja. Ariani (2014) menjelaskan bahwa "Aturan di tempat kerja adalah hasil interaksi antara pengusaha dengan karyawan, sehingga melahirkan berbagai peraturan di lingkungan perusahaan dalam bentuk kesepakatan kerja bersama." Peraturan tersebut melakat dan mengikat kepada para pihak, baik pihak karyawan maupun pihak pengusaha.

Apabila terjadi ketidaksesuaian antara pegawai dengan pengusaha yang tertera pada peraturan perusahaan, maka akan menimbulkan perselisihan hubungan industrial. Menurut Harsono dan Ambarepto dalam Fatyandri dan Muchsinati (2014) perselisihan hubungan industrial, meliputi: (a) Perselisihan hak merupakan perselisihan terjadi karena adanya perbedaan pelaksanaan atau ketidaksesuaian terhadap ketentuan peraturan perundangan, perjanjian kerja, peraturan perusahaan, dan perjanjian kerja bersama; (b). Perselisihan kepentingan merupakan perselisihan terjadi dalam hubungan kerja karena ketidaksesuaian pendapat mengenai perbuatan, syarat - syarat kerja yang dibuat dalam perjanjian kerja.

Harsono (2006) berpendapat "dalam menanggulangi masalah hubungan industrial, 
perlu adanya suatu upaya dan langkah kongkrit dari pihak pengusaha/pimpinan perusahaan. Upaya penting tersebut meliputi penerapan peraturan perundang-undangan, membina pegawai serta menjalin komunikasi dan memberikan perhatian kepada para pegawai yang berkaitan dengan peningkatan kesejahteraan.”

Peran pimpinan sangat diperlukan untuk mengatasi perselisihan antar pegawai dengan manajemen. Mediasi merupakan solusi terbaik dalam penyelesaian secara bipartit (internal). "Mediasi adalah suatu proses penyelesaian sengketa Alternatif di mana pihak ketiga yang dimintakan bantuannya untuk membantu proses penyelesaian sengketa bersifat pasif dan sama sekali tidak berhak atau berwenang untuk memberikan suatu masukan, terlebih lagi untuk memutuskan perselisihan yang terjadi, jadi dalam mediasi, mediator hanya berfungsi sebagai Penyambung lidah dari para pihak yang bersengketa, perantara yang demikian kadangkala memang diperlukan, baik dalam hal para pihak yang bersengketa tidak mungkin bertemu sendiri karena berbagai faktor yang berada di luar kemampuan mereka.” Menurut Pradima, Akbar (2013).

Pradima (2013) berpendapat bahwa"Perundingan bipartit pada hakekatnya merupakan upaya musyawarah untuk mufakat antara pengusaha dan pihak pekerja/buruh." adapun lingkup penyelesaian perselisihan hubungan industrial melalui bipartit yaitu perselisihan hak, perselisihan kepentingan, perselisihan PHK dan perselisihan antar serikat pekerja/serikat buruh dalam satu perusahaan. Penyelesaian perselisihan hubungan industrial dengan melalui perundingan secara musyawarah mufakat antar pengusaha dengan pekerja atas dasar rasa kekeluargaan.

Peran pimpinan sebagai mediator perselisihan sudah barang tentu harus memiliki komptensi utama dalam menyelesaikan hubungan industrial. Fatyandri dan Muchsinati (2014) "Kompetensi didefinisikan sebagai kemampuan personal yang terdiri dari kemampuan keahlian didalam suatu bidang, kemampuan pengetahuan, dan kemampuan berperilaku yang dapat digunakan sebagai alat ukur untuk mengukur kinerja seseorang." Kompetensi tersebut dapat berupa komunikasi dua arah antara pegawai dengan manajemen. Apabila tidak efektif dalam komunikasi maka akan menimbulkan kesenjangan komunikasi.

Fatyandri dan Muchsinati (2014) “Kesenjangan komunikasi dapat menyebabkan perbedaan sudut pandang antara pekerja dengan perusahaan yang dapat menimbulkan persepsi pekerja merasa diperlakukan secara tidak adil. Manajemen yang tidak 
mengkomunikasikan visi, misi, dan nilai perusahaan kepada pekerja akan menimbulkan kesenjangan yang semakin lebar antara pekerja dan perusahaan"

\section{Penelitian Terdahulu}

Hasil Penelitian Prayuginingsih dkk (2012) menyatakan bahwa model harmonisasi hubungan industrial perlu disempurnakan dalam bentuk: (1) perbaikan atribut perlindungan, pengadaan lembaga keuangan pengganti koperasi, pemberian asuransi pengganti Jamsostek, peningkatan pengetahuan buruh akan keberadaan SPSI, perbaikan hubungan buruh-SPSI dan buruh-perusahaan; (2) melibatkan ATI mendampingi pemerintah dalam mengawasi dan memfasilitasi hubungan industrial pada gudang tembakau; (3) peran mandor sebagai mediator buruh-perusahaan digantikan kepala gudang yang mempunyai kedudukan lebih strategis di SPSI. Hasil simlasi penerapan model hanya mampu meningkatkan skor perlindungan dan kepuasan kerja namun tidak pada hubungan industrial. Hanya gudang PT Perkebunan Nusantara yang mempunyai hubungan industrial harmonis sebelum dan sesudah penerapan model.

Penelitian Grant (2011) dengan judul Developing a Competency Framework for Labour Relations Professionals menyatakan bahwa hubungan industrial perlu memiliki lebih dari satu dasar pengetahuan dan keterampilan serta kompetensi yang meliputi negosiasi, resolusi konfilk, mediasi, arbitrase, dan perundingan bersama.

Hasil penelitian Fatyandri dan Muchsinati (2014) dengan judul Pengaruh dan Peran Manajer SDM Terhadap Keharmonisan Hubungan Industrial Di Kota Batam menunjukan bahwa keharmonisan hubungan industrial di dalam perusahaan sangat erat hubungannya dengan peran dari Manajer SDM dan perwakilan pekerja/serikat pekerja dalam menyikapi terhadap perselisihan yang terjadi. Komunikasi yang rutin dan efektif serta fungsi kemitraan selalu dijaga sehingga perselisihan tidak akan terjadi apabila masing-masing pihak bisa menghormati ketentuan dan peraturan perundangan yang berlaku. Musyawarah untuk mufakat dalam setiap permasalahan/perselisihan harus menjadi kunci utama.

\section{Kerangka Berfikir}

Keharmonisan hubungan industrial dapat terbentuk apabila perselisihan atas hak dan kepentingan dapat diselesaikan dalam internal organisasi. Peraturan atau kebijakan yayasan atau manajemen yang menjadi panduan dan dilaksanakan oleh semua pegawai UBP Karawang. Namun apabila terdapat ketidak sesuaian hak dan kepentingan maka akan timbul perselisihan. Maka peran pimpinan merupakan aspek penting untuk menjaga keharmonisan hubungan industiral di lingkungan kampus UBP Karawang. Dengan demikian tergambar dalam skema 
sebagai berikut:

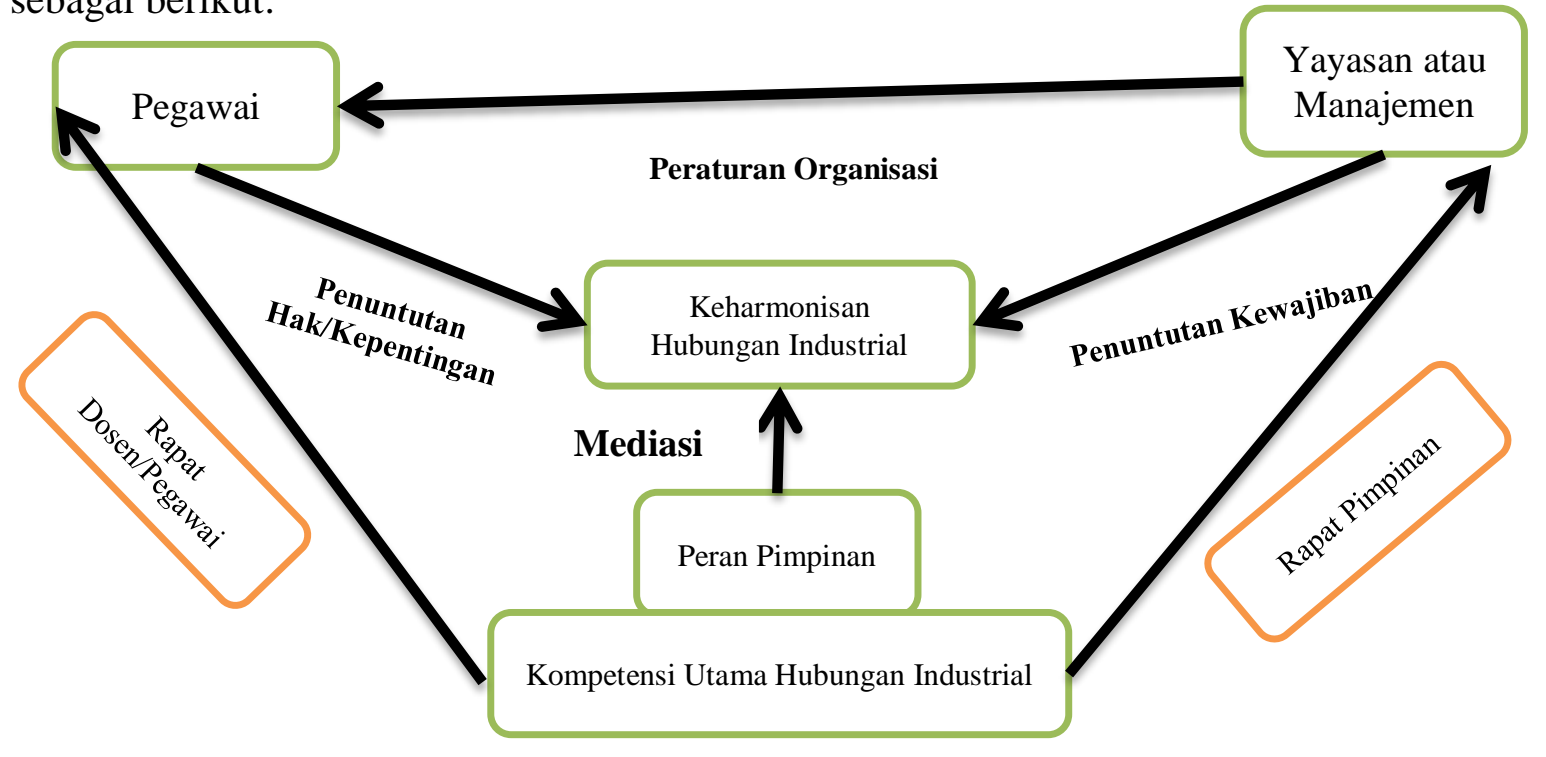

Gambar 1 Kerangka Berfikir

\section{Metode Penelitian}

Penelitian ini menggunakan metode penelitian pendekatan deskriptif kualitatif. Metode deskriptif merupakan salah satu metode yang dapat digunakan untuk menggambarkan dan menganalisis suatu hasil penelitian atau pengamatan namun tidak dapat digunakan untuk membuat kesimpulan yang luas.

\section{Lokasi Penelitian}

Penelitian dilakukan di lingkungan Universitas Buana Perjuangan Karawang .

\section{Intrumen Penelitian}

Sebagai pedoman dalam wawancara, seyogyanya menyusun dan membuat instrumen penelitian sebagai berikut:

Tabel 1

Intrumen Penelitian

\begin{tabular}{|c|c|c|}
\hline Variabel & Dimensi & Indikator Wawancara \\
\hline \multirow{10}{*}{$\begin{array}{l}\text { Hubungan } \\
\text { Industrial }\end{array}$} & \multirow[t]{3}{*}{ Fungsi Manajemen SDM } & Fungsi Pimpinan sebagai MSDM \\
\hline & & Tantangan Pimpinan mengelola SDM \\
\hline & & $\begin{array}{l}\text { Pembagian waktu sebagai fungsi strategik } \\
\text { lembaga dengan fungsi MSDM }\end{array}$ \\
\hline & \multirow{5}{*}{$\begin{array}{l}\text { Perselisihan Hubungan } \\
\text { Industrial }\end{array}$} & Pengetahuan Hubungan industrial \\
\hline & & Jalur komunikasi hubungan industrial \\
\hline & & Hubungan pimpinan dengan pegawai \\
\hline & & $\begin{array}{l}\text { Intensitas perselisihan antar pegawai } \\
\text { dengan lembaga }\end{array}$ \\
\hline & & Penyelesaian perselisihan \\
\hline & \multirow[t]{2}{*}{ Kompetensi Pimpinan } & Kompetensi inti dalam mengelola MSDM \\
\hline & & Upaya lembaga untuk meningkatkan \\
\hline
\end{tabular}


Sumber: Olah data 2019

kompetensi inti

\section{Populasi dan Sampel}

Populasi yang digunakan dalam penelitian ini adalah civitas akademik yang berbekerja di UBP Karawang. Teknik pemilihan sampel menggunakan cluster sampling. Menurut Jogiyanto (2007:78) pengambilan cluster sampling dapat dilakukan dengan membagi populasi menjadi beberapa grup bagian. Grup bagian disebut dengan cluster. Beberapa cluster kemudian dipilih secara random. Jumlah sampel dalam penelitian ini adalah 5 Pimpinan yang mewakili beberapa fakultas dan rektorat yang ada dilingkungan UBP Karawang.

\section{Instrumen Pengumpulan Data}

Data yang dapat digunakan dalam penelitian ini adalah data primer. Data primer adalah data yang diperoleh secara langsung dari responden baik berupa wawancara maupun kuesioner. Sedangkan teknik pengumpulan data dapat dilakukan dengan survey dengan mewancarai secara tatap muka langsung dengan responden. Metode ini dihrapakan memperoleh informasi yang efektif tentang peran pimpinan didalam lembaga perguruan tinggi dengan menggunakan bantuan alat rekam pada saat wawancara.

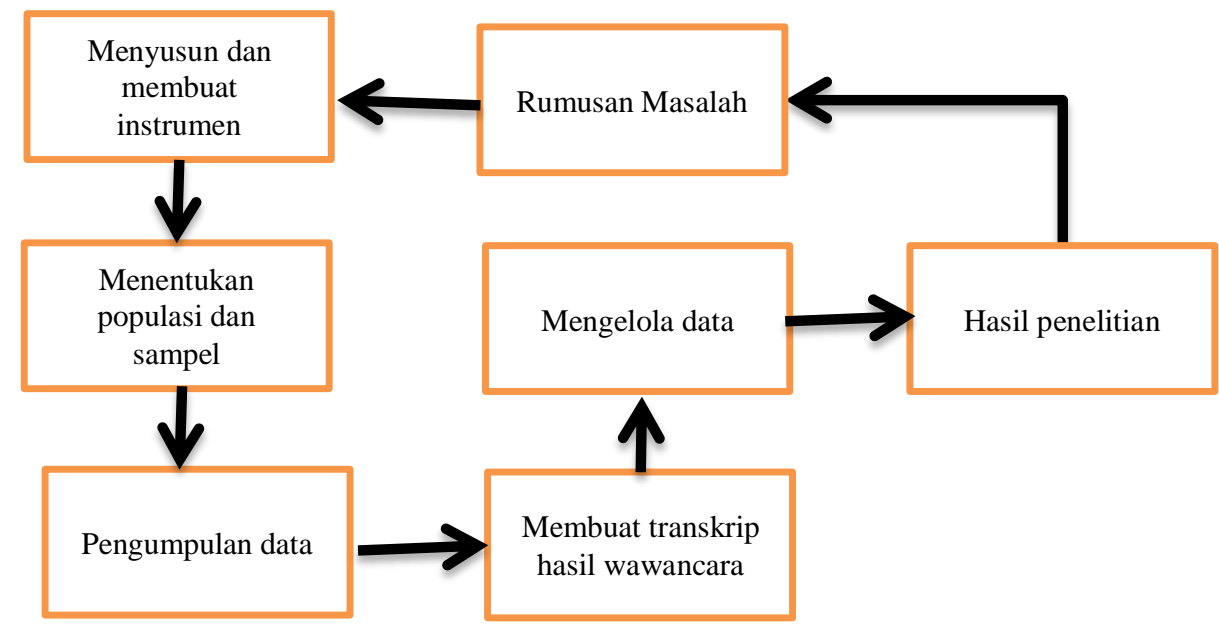

\section{Gambar 2. Prosedur Penelitian}

\section{Jenis Penelitian}

Penelitian ini merupakan jenis penelitian terapan dengan maksud menyelidiki suatu masalah dengan bertujuan untuk digunakan sesuai dengan keperluan tertentu secara sistematis. Sedangkan data yang digunakan menggunakan data kualitatif yaitu data yang tidak berbetuk angka tetapi data berbentuk pernyataan yang merangkai kalimat. Adapun 
metode analisis yang digunakan berupa analisis deskriptif yakni menganalisis hasil jawaban pertanyaan responden yang diinterprestasikan dengan kaitannya masalah hubungan industrial.

\section{Hasil Pembahasan Penelitian}

Hasil analisis berdasarkan dari pengumpulan data melalui wawancara yang dilakukan dengan Pimpinan UBP Karawang, maka diketahui bahwa untuk menjadi Pimpinan dilingkungan civitas akademik UBP Karawang dalam mengelola hubungan industrial diperlukan kompetensi keahlian khusus seperti memahami fungsi manajemen sumber daya manusia dan mampu menyelesaikan pertikaian dan perselisihan dalam hubungan industrial secara internal.

Pada dasarnya pimpinan sudah memahami fungsi manajemen sumber daya manusia secara utuh, mulai dari (1) perencanaan sumber daya manusia meliputi rekrutmen, seleksi, dan penempatan; (2) pengembangan sumber daya manusia meliputi pelatihan kerja, perencanaan karir, manajemen talenta, kompensasi, pengukuran kinerja dan lainnya; (3) hubungan industrial meliputi konflik dan penyelesainya serta keharmonisan pegawai dengan lembaga; (4) pemutusan hubungan kerja meliputi PHK dan pensiun. Penanganan persoalan hubungan industrial menjadi fungsi manajemen sumber daya manusia yang memiliki tantangan tersendiri, kemampuan berkomunikasi yang efektif dan bernegosiasi menjadi kompetensi mutlak yang harus dimiliki oleh Pimpinan dalam menghadapi pegawai yang menuntut hak maupun kepentingan.

Administrasi manajemen sumber daya manusia merupakan fungsi yang mudah dilakukan oleh siapa saja. Kegiatan administrasi berupa merekap dokumen-dokumen, mengarsipkan dan mengirim surat menyurat, rekap kehadiran pegawai, pengupahan pegawai, dan kegiatan administrasi lainnya. Kegiatan tersebut seyogyanya tidak dilakukan oleh pimpinan, namun dapat dikerjakan oleh staf yang bagian khusus untuk adminstrasi.

Fungsi strategik yang dilaksanakan oleh pimpinan Pada umumnya seperti fungsi perencanaan dan pengawasan dalam mengelola kegiatan manajemen sumber daya manusia. Fungsi perencanaan, pimpinan dapat membantu top manajemen (yayasan) dalam menentukan arah kebijakan dan strategi, baik berupa strategi pengelolaan bisnis maupun strategi pengelolaan sumber daya manusia yang dapat dilaksanakan secara berkesinambungan. Sedangkan fungsi pengawasan, pimpinan dapat mengevaluasi dan memonitoring kegiatan atau tugas-tugas yang sudah didelegasikan kepada staf yang sifatnya rutin dan administrasi. 
Perselisihan hubungan indsutrial pada umunya terjadi karena adanya perselisihan hak yang telah diatur di dalam peraturan kepegawaian dan statuta dari yayasan yang berlaku. Perselihan juga dapat terjadi karena adanya perselisihan kepentingan di mana terjadinya penyimpangan atas syarat-syarat atau ketentuan yang telah diatur atau disepakati sebelumnya.

Hubungan indsustrial dalam pengelolaanya merupakan salah satu pekerjaan yang sulit, hal tersebut menyangkut hubungan tingkat kepentingan pegawai dengan peraturan yang sudah ditetapkan. Terkadang apabila tidak bisa diselesaikan secara bipartit (internal), maka tripartit (melibatkan pihak eksternal) dalam hal ini pemerintah yang tidak bisa dielakan.

Peran pimpinan dalam membangun hubungan industrial yang harmonis di UBP Karawang, tercatat dalam skema gambar sebagai berikut:

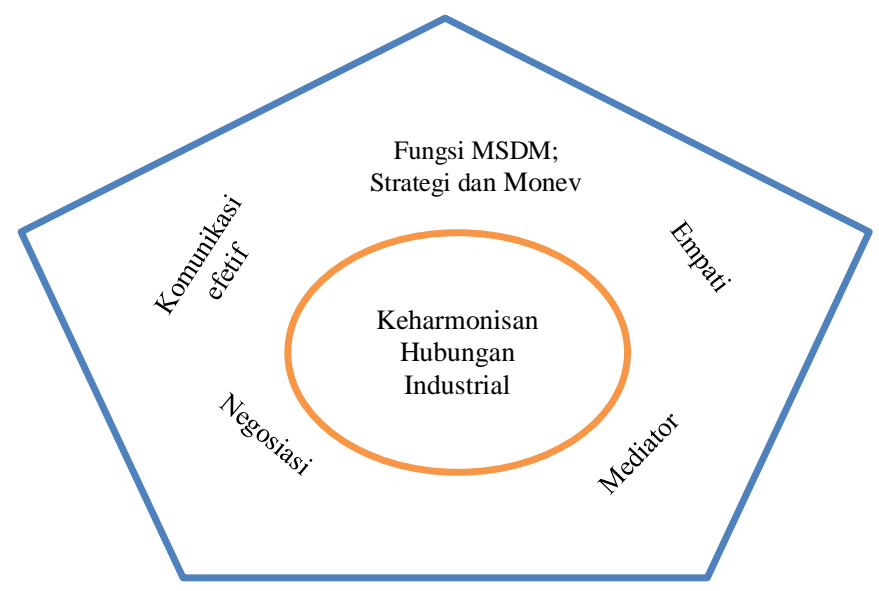

\section{Gambar 3 Desain Hubungan Indsutrial}

Komunikasi merupakan kunci utama dalam pengelolaan hubungan industrial. Setiap pemimpin harus memahami dan mengerti dari maksud dan tujuan atas perselisihan yang terjadi. Pimpinan UBP Karawang biasanya menggunakan rapat dosen dan rapat senat yang diwakili oleh dosen selain pimpinan sebagai forum komunikasi lainnya. Pertemuan rutin lainnya yang sifat rutin perlu dilakukan pada setiap bulannya, sehingga komunikasi dua araha antara manajemen dengan pegawai dapat terjalin hubungan yang harmonis.

Ketidakefektifan komunikasi dapat menimbulkan masalah berjalan terus menerus dan berlarut-larut. Hal tersebut terjadi karena tidak ada keterbukaan baik dari pihak pimpinan maupun dari pihak pegawai. Dampak dari berlarut-larut masalah diantaranya pegawai tidak melakukan kegiatan tridarma perguruan tinggi seperti pengajaran tidak efektif, malas melakukan penelitian dan pengabdian, begitu juga dengan kegiatan penunjang lainnya seperti tidak berjalannya kepanitiaan walaupun pegawai tersebut ditunjuk sebagai anggota 
panitia namun tidak mengerjakan.

Salah satu Pimpinan yang menyampaikan bahwa masalah yang ada pada pegawai selalu disampaikan di rapat dosen, atau rapat pimpinan yang diselenggarakan setiap bulan untuk rapat dosen sedangkan untuk rapat pimpinan setiap minggu. Masalah kedisiplinan, masalah tidak mengerjakan tridarma perguruan tinggi selalu menjadi pembahasan di agenda rapat tersebut. Begitu juga masalah kenaikan gaji atau tunjangan juga menjadi agenda tahunan dari pegawai yang berujung pada perbincangan antar pegawai "dibelakang" dan antar pimpinan karena nilai yang diharapkan pegawai tidak sesuai dengan harapan.

Apabila perselisihan hubungan industrial terjadi, maka yang berperan menjadi mediator adalah pimpinan. Pimpinan wajib mempunyai kemampuan negosiasi sehingga musyawarah yang mufakat dapat diutamakan dari pada kediktatoran dan arogansi dari masing-masing pihak. Penyelesaian perselisihan sebaiknya dapat dilakukan secara internal tanpa melibatkan pihak peerintah, dan tidak dirahapkan perselisihan sampai ke pengadilan perselisihan hubungan internasional.

Para pihak wajib menghormati kebijakan, peraturan dan perundangan yang berlaku maka permasalahan dapat diselesaikan dengan kepala dingin dan selesai hanya ditingkat lembaga saja. Dan biasanya UBP Karawang menyelesaikan permasalah ditingkat lembaga apabila terjadi pertikaian antar pegawai, maka diselesaikan secara bipartit.

Pimpinan bukan hanya memiliki kompetensi atas pemahaman peraturan dan perundangan yang berlaku mengenai ketenagakerjaan, namun memahami dan mengerti atas fungsi manajemen yakni perencanaan dan pengawasan secara keseluruhan, komunikasi efektif, negosiasi, empati kepada pegawai harus selalu melekat sebagai kompetensi utama sebagai pimpinan.

Peran pimpinan sebagai mediator untuk penyelesaian perselisihan hubungan industrial juga sangat dibutuhkan. Yayasan memeberikan keleluasaan kepada pimpinan baik dalam pengembangan diri pimpinan maupun pengembangan sumber daya manusia secara keseluruhan dilingkungan internal UBP Karawang. Posisi strategik yang dipegang oleh pimpinan tentu mengetahui apa yang dibutuhkan oleh pegawai, diri peribadi dan kemajuan lembaga. Pimpinan dapat membuat program pengembangan sumber daya manusia dengan meng acu pada sasara jangka pendek, jangka menengah dan jangka panjang. Diharapkan program tersebut dapat membantu pegawai mengembangkan diri sendiri dan kepuasan atas pekerjaannya sehingga perselisihan tidak terjadi.

\section{Kesimpulan dan Saran}




\section{Kesimpulan}

E ISSN : $2580-5517$

Penelitian ini dapat memberikan kesimpulan bahwa hubungan industrial yang harmonis dapat dipengaruhi oleh peran pimpinan melalui pendekatan kepada pegawai dengan komunikasi yang efektif dan bersifat empati kepada dalam hal menyikapi perselisihan. Komunikasi yang rutin dapat juga menjaga keharmonisan pimpinan dengan pegawai.

Peran pimpinan untuk membangun hubungan industrial yang harmonis dengan cara membuat pertemuan pimpinan secara rutin baik dalam rapat dosen, maupun rapat pimpinan. Komunikasi efektif, memahami dan mengerti atas fungsi manajemen yakni perencanaan dan pengawasan secara keseluruhan, negosiasi, empati kepada pegawai harus selalu melekat sebagai kompetensi utama. Apabila terjadi perselisihan, pimpinan sebagai mediator dan diselesaikan secara internal.

\section{Saran}

Berdasarkan hasil dan pembahasan, penulis menyarankan dalam menjaga keharmonisan hubungan industrial yaitu:

1. Dalam membangun hubungan industrial yang harmonis sudah barang tentu tidaklah mudah, namun dapatlah dimulai dengan komunikasi yang baik secara rutin dan bersifat empati terhadap keluh kesah bawahan (pegawai) itu lebih baik dari pada mendahulukan arogansi sesaat.

2. Peran pimpinan dalam mempengaruhi hubungan industrial sudah pasti memiliki adil dalam keharmonisan. Misalnya sebagai mediator apabila terjadi perselisihan, namun hal tersebut tidaklah cukup, perlu kompetensi utama yang harus dimiliki oleh setiap pimpinan seperti empati, komunikasi efektif, kemampuan negosiasi, pemahaman fungsi manajemen, dan sebagai mediator yang handal.

\section{Daftar Pustaka}

Ariani, Dorothea Wahyu. 2014. Hubungan Industrial. Tanggerang: Universitas Terbuka.

Fatyandri,Adi Neka dan Evi Silvana Muchsinati. 2014. Pengaruh Dan Peran Manajer Sdm Terhadap Keharmonisan Hubungan Industrial Di Kota Batam. Batam: Universitas Internasional Batam, Jurnal Manajemen, Vol.14, No.1

Grant, A. (2011), "Developing a Competency Framework for Labour Relations Professionals", University IRC Labour Relations Programs 
E ISSN : $2580-5517$

Harsono, Mugi. 2006. Analisis Beberapa Faktor Yang Mempengaruhi Harmonisasi Hubungan Kemitraan Antara Pekerja Dan Pengusaha. Surakarta: Universitas Sebelas Maret Surakarta. Jurnal Manajemen Sumber Daya Manusia Vol. 1

Idris, Fahmi. 2018. Dinamika Hubungan Industrial. Yogyakarta: CV. Budi Utama

Jogiyanto (2007), "Metodologi Penelitian Bisnis: Salah Kaprah dan Pengalaman Pengalaman", BPFE, Yogyakarta.

Pradima, Akbar. 2013. Alternatif Penyelesaian Perselisihan Hubungan Industrial di Luar Pengadilan. Surabaya:Universitas 17 Agustus 1945. Fakultas Hukum Jurnal Ilmu Hukum Vol 9 No 17.

Prayuginingsih, Henik, Teguh Hari Santosa dan Muhammad Iman. 2012. Uji Keandalan Model Harmonisasi Hubungan Industrial pada Gudang Tembakau di Kabupaten Jember. Jember: Universitas Muhamadiah Jember Jurnal Manajemen Dan Kewirausahaan, Vol.14, No. 1

Undang-Undang Ketenagakerjaan No. 13 tahun 2003 